\title{
RESENHA
}

\section{UM OLHAR SOBRE A HISTÓRIA DA CRECHE NA EUROPA (SÉCULOS 19 E 20)}

DOI: http://dx.doi.org/10.1590/2236-3459/64918

\author{
Maria Helena Camara Bastos \\ Pontifícia Universidade Católica do Rio Grande do Sul, Brasil.
}

$\cos 8$

CAROLI, Dorena. Per uma storia dell'asilo nido in Europa tra otto e novencento. Milano: FrancoAngeli, 2014.

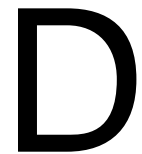

orena Caroli é professora de História da Educação no Dipartimento di Scienze della formazione, dei beni culturali e del turismo da Università degli studi di Macerata/ltália. É pesquisadora do Centro di documentazione e ricerca sulla storia del libro scolastico e della letteratura per I'infanzia/Cesco. Atualmente pesquisa sobre a história da literatura infantil na Rússia e União Soviética e integra a equipe editoral da revista History of Education \& Children's Literature. Junto com a professora Anna Ascensi coordena a Collona di Storia delle Istituzioni Educative e della Letteratura per I'Infanzia, FrancoAngeli/Milão.

Suas obras mais recentes são: L'enfance abandonnée et delinquente dans la Russie soviétique (1917-1937); Ideali, ideologie e modelli formativi : il movimento dei Pionieri in URSS (1922-1939); La protection sociale en Union Soviétique (1917-1939); Citadini e patrioti : educazione, letteratura per l'infanzia e formazione dell'identità nazionale nella Russia soviética; Un Welfare State senza benessere: insegnanti, impiegati, operai e contadini nel sistema di previdenza sociale dell'Unione Sovietica (19171939).

Per uma storia dell'asilo nido in Europa tra otto e novencento busca reconstruir a 
história da instituição creche para crianças e mães, desde o nascimento até a entrada no sistema escolar - escola maternal ou jardim de infância. Para tal, prospecta 0 atendimento da faixa etária de zero a dois anos em cinco países europeus: França, Inglaterra, Alemanha, Rússia e Itália nos séculos 19 e 20, até o final da segunda grande guerra.

A obra estrutura-se em três partes com apoio em uma vasta e consistente pesquisa documental e de obras de referências sobre o tema, especialmente de médicos e de educadores dos séculos 19 e 20, explicitadas na bibliografia e no índice de nomes (p. 347-369). A primeira parte aborda o nascimento da creche e da puericultura moderna na França e na Inglaterra. Na segunda, a autora dedica-se a analisar a realidade da Alemanha e da Rússia. Por fim, na terceira parte, analisa a difusão do modelo francês na Itália. Uma primeira constatação da autora é a diversidade de denominações adotadas em cada país para essa etapa de vida: crèche, na França; presepe depois asilo nido, na Itália; day nursey, na Inglaterra; Krippe, na Alemanha; detskij jasel e, depois, jasel-prijut, na Rússia

A emergência dessa instituição, que nasce na França - crèche -, ocorre, principalmente, a partir da segunda metade do século $19 \mathrm{com}$ a inserção cada vez maior da mulher no mercado de trabalho, no âmbito industrial e urbano, o que passou a requer um lugar para deixar o bebê durante a jornada diária. Inicialmente não tinha fins educativos, mas de acolhimento da primeiríssima infância e, especialmente, das mães diante da recomendação cada vez maior de médicos e higienistas quanto à prática do aleitamento.

A sua expansão também está ligada à política de redução da mortalidade infantil e de prevenção ao abandono, prática frequente nesses países no século 19. A autora assinala que a proibição da roda dos expostos foi um dos dispositivos adotados para restringir o número de crianças rejeitadas, que era muito elevado. Esse contexto europeu marcou o nascimento das creches como instituição de caráter assistencial e filantrópico, decorrente de uma política de higiene social voltada às mães das classes populares, com o objetivo de civilizar a sociedade.

Num primeiro momento, a creche foi uma instituição assistencial e filantrópica, a cargo de ordens religiosas ou com a participação de sociedades de caridade criadas por damas da sociedade. A partir, principalmente, do final do século 19 e início do 20 passou por um processo de laicização sob a tutela do poder público e da sociedade civil. Também há uma gradativa preocupação com a formação e profissionalização do pessoal que atuava nas creches, envolvidos diretamente com as crianças ou com a administração.

Dorena Cairoli assinala que a difusão do modelo francês de creche para a primeiríssima infância foi acompanhada por uma série de reformas, tanto de caráter assistencial, quanto de um discurso científico voltado à criança - puericultura na França, pediatria na Alemanha e neonatologia na Itália - o que contribuiu para sua institucionalização como um instrumento da política de higiene social e demográfica na maioria dos países europeus.

Dos discursos médicos e de higienistas, junto com a divulgação da puericultura e de um serviço social destinado à primeiríssima infância, decorreu toda uma legislação de proteção da mulher durante o período de maternidade - da gestação aos primeiros meses de vida da criança. Gradativamente, a creche passou de uma instituição assistencial e filantrópica a uma instituição educativa, em especial a partir da contribuição de inúmeros 
pensadores, como Jean-Jacques Rousseau, Johann Heinrich Pestalozzi, Friederich Froebel, Maria Montessori. Para isso contribuiu, também, o desenvolvimento da psicopedagogia, da psicologia da linguagem, da psicologia do jogo.

A autora conclui sua consistente e pertinente análise do longo processo histórico da institucionalização da creche chamando a atenção para a articulada correlação de diferentes discursos - médico, higienista, sociológico, educativo, psicopedagógico - que pensam a primeiríssima infância no espaço europeu e, também, internacional, ontem e hoje. Considera que essa correlação de discursos e a progressiva transformação da creche como espaço pedagógico foi fundamental "para a formação profissional dos educadores como a interação e comunicação entre o neonatal e mãe/pai e outros adultos, criando uma nova consciência diante da maternidade e da paternidade dedicada a uma cidadania ativa e democrática" (CAROLI, 2014, p. 346).

A obra de Dorena Cairoli é importante, tanto pelo aspecto historiográfico, quanto para a formação dos profissionais envolvidos no universo da criança e da infância.

MARIA HELENA CAMARA BASTOS é professora na Pontifícia Universidade Católica do Rio Grande do Sul. Professora visitante na Università degli studi di Macerata/Itália.

Endereço: Rua Eng. Álvaro Nunes Pereira, 340/906 - 90570-110 - Porto Alegre/RS - Brasil.

E-mail: mhbastos1950@gmail.com

Recebido em 22 de maio de 2016.

Aceito em 10 de dezembro de 2016. 